\title{
Surgical resection of solitary omental metastasis from non-small cell lung cancer: Report of three cases
}

\author{
YASUHIRO MATSUDA, YOSHIYUKI FUJIWARA, KENTARO KISHI, JIRO OKAMI, KEIJIRO SUGIMURA, \\ MASAAKI MOTOORI, NORIKATSU MIYOSHI, SHINGO NOURA, MASAYUKI OHUE, KUNIHITO GOTOH, \\ SHIGERU MARUBASHI, HIROFUMI AKITA, HIDENORI TAKAHASHI, MASATO SAKON and MASAHIKO YANO
}

Department of Surgery, Osaka Medical Center for Cancer and Cardiovascular Diseases, Higashinari-ku, Osaka 537-8511, Japan

Received June 9, 2014; Accepted March 2, 2015

DOI: $10.3892 / \mathrm{ol} .2015 .3942$

\begin{abstract}
In the present study we report three cases of solitary omental metastasis from non-small cell lung cancer, which had been surgically resected at our institute. The primary site was resected in one patient (case 1) and the other two patients were treated with chemotherapy and demonstrated complete response (cases 2 and 3). The omental metastasis appeared 4 months after pneumonectomy in case 1 . Two metachronous omental tumors appeared 55 and 79 months after the initial chemotherapy in case 2 . In Case 3 , an omental tumor appeared 6 months after chemotherapy. Case 1 succumbed to recurrence 8 months after the resection of the omental tumor. Case 2 survives with recurrent disease 8 months after resection of the second omental metastasis, and case 3 survives 6 months after resection of the omental tumor. Although omental metastasis from non-small cell lung cancer is extremely rare, it should be considered when a patient with history of lung cancer has a tumor around the stomach.
\end{abstract}

\section{Introduction}

Non-small cell lung cancer (NSCLC) is the most common neoplasm and remains the leading cause of cancer-related mortality worldwide (1). In 2008, a total of 1.6 million new cases of lung cancer were diagnosed worldwide, accounting for $13 \%$ of all cancer cases. Furthermore, lung cancer accounted for 1.4 million mortalities and $18 \%$ of all cancer-related mortalities worldwide in 2008 (1). The most common symptoms of lung cancer include fatigue, loss of appetite, shortness of breath, cough, pain and blood in the sputum (2). The majority of lung cancer cases $(80 \%)$ are classified as NSCLC (3). Of these

Correspondence to: Dr Yoshiyuki Fujiwara, Department of Surgery, Osaka Medical Center for Cancer and Cardiovascular Disease, 1-3-3 Nakamichi, Higashinari-ku, Osaka 537-8511, Japan E-mail: fujiwara-yo@mc.pref.osaka.jp

Key words: omental metastasis, non-small cell lung cancer, pleomorphic carcinoma patients, $>65 \%$ present with locally advanced or metastatic disease (4). Surgical resection is the most effective treatment for early-stage NSCLC. However, despite complete surgical resection, $30-75 \%$ of patients with stage I-IIIA NSCLC suffer a relapse and succumb to the disease $(1,5,6)$. The most common sites of recurrence are the regional lymph nodes, lung, liver, bone, brain and adrenal gland (7). We experienced three cases of rare solitary omental metastasis of NSCLC, which had been subjected to surgical resection.

This study describes the clinical characteristics and outcome of the three patients with solitary omental metastasis of NSCLC and also reviews the literature reported previously. The study was approved by the ethics committee of Osaka Medical Center for Cancer and Cardiovascular Diseases (Osaka, Japan), and written informed consent was obtained from the patient or the patient's family.

\section{Case report}

Case 1. A 72-year-old female with a history of cigarette smoking [Brinkman index (BI), 525] who had a left lower lobe lung cancer (squamous cell carcinoma) underwent left lower lobe resection and mediastinal lymph node dissection. Postoperative chemotherapy was not enforced. The solitary abdominal tumor was diagnosed with ${ }^{18} \mathrm{~F}$-fluorodeoxyglucose positron emission tomography and computed tomography (PET/CT) 4 months after pneumonectomy and was referred to the Department of Surgery at the Osaka Medical Center for Cancer and Cardiovascular Diseases. Physical examination was not noteworthy. The laboratory examination revealed serum carcinoembryonic antigen (CEA) of $3.3 \mathrm{ng} / \mathrm{dl}$ (normal range, $0-5 \mathrm{ng} / \mathrm{dl}$ ) and CA19-9 of $41 \mathrm{U} / \mathrm{ml}$ (normal range, $<37 \mathrm{U} / \mathrm{ml}$ ). A CT examination was performed and revealed an enhanced solitary tumor measuring 30x26 mm around the stomach (Fig. 1A). The maximum standardized uptake value (SUV Max) was 4.055 on the PET/CT (Fig. 1B). Laparotomy was performed and a tumor was detected in the greater omentum, which had invaded into the transverse colon. The tumor was resected, and partial resection of the transverse colon was also performed. Histopathological examination with hematoxylin and eosin revealed poorly differentiated invasive squamous cell carcinoma. The patient was followed 
Table I. Characteristics and treatment of primary non-small cell lung cancer.

\begin{tabular}{llcclccc}
\hline $\begin{array}{c}\text { First } \\
\text { No. }\end{array}$ & \multicolumn{1}{c}{ author (ref.) } & Age & Gender & Histological type & Stage & $\begin{array}{c}\text { Treatment for } \\
\text { primary tumor }\end{array}$ & $\begin{array}{c}\text { Time to } \\
\text { metastasis }\end{array}$ \\
\hline 1 & Nakamura et al (8) & 61 & M & Large cell carcinoma & IV & Resection & 0 \\
2 & Oshika et al (9) & 44 & M & Large cell carcinoma & IV & Resection & 0 \\
3 & & 60 & M & Adenocarcinoma & IB & Resection & 0 \\
4 & Tamura et al (10) & 50 & M & Pleomorphic carcinoma & IA & Resection & 5 months \\
5 & Present case 1 & 72 & F & Squamous cell carcinoma & IB & Resection & 4 months \\
6 & Present case 2 & 64 & M & Pleomorphic carcinoma & IIIB & Chemotherapy; radiation & 46 months \\
7 & Present case 3 & 59 & M & Pleomorphic carcinoma & IIIB & Chemoradiation & 6 months \\
\hline
\end{tabular}

$\mathrm{M}$, male; F, female. ${ }^{\mathrm{a} T h e}$ present case 2 had radiation therapy for lymph node metastases 14 months after initial chemotherapy. ${ }^{\mathrm{b}}$ First omental recurrence was confirmed 46 months after the treatment of primary non-small cell lung cancer.

Table II. Treatment outcome of solitary omental metastasis from non-small cell lung cancer.

\begin{tabular}{|c|c|c|c|c|c|}
\hline \multirow[b]{2}{*}{ No. } & \multirow[b]{2}{*}{ Treatment for omental tumor } & \multirow[b]{2}{*}{ Infiltration } & \multicolumn{2}{|c|}{ Recurrence following omentectomy } & \multirow[b]{2}{*}{ Outcome $^{c}$} \\
\hline & & & Period $^{\mathrm{a}}$ & Treatment & \\
\hline 1 & Resection; chemoradiation & None & & None & 13 months (relapse-free) \\
\hline 2 & Resection; chemotherapy & None & & None & 14 months (relapse-free) \\
\hline 3 & Resection; chemotherapy & None & & None & 14 months (relapse-free) \\
\hline 4 & Resection & None & 3 weeks & None & 7 months, deceased \\
\hline 5 & Resection & Colon & 3 months & None & 8 months, deceased \\
\hline 6 & $\begin{array}{l}\text { Resection } \\
\text { Resection }\end{array}$ & $\begin{array}{l}\text { None } \\
\text { None }\end{array}$ & $\begin{array}{l}24 \text { months }^{\text {b }} \\
8 \text { months }\end{array}$ & $\begin{array}{l}\text { Resection } \\
\text { Chemotherapy }\end{array}$ & $\begin{array}{l}40 \text { months, alive } \\
\text { with recurrence }\end{array}$ \\
\hline 7 & Resection; chemotherapy & $\begin{array}{l}\text { Stomach, } \\
\text { pancreas }\end{array}$ & None & Chemotherapy & $\begin{array}{l}20 \text { months, alive with } \\
\text { recurrence }\end{array}$ \\
\hline
\end{tabular}

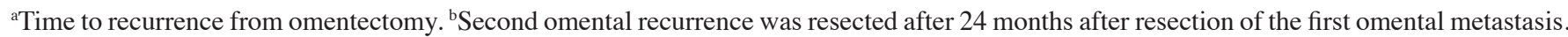
${ }^{\mathrm{c}}$ Clinical outcome following resection of omental tumor. ${ }^{\mathrm{d}}$ Case 2 was alive with recurrence 40 months after resection of the first omental tumor.

up without postoperative chemotherapy and succumbed to recurrent disease in the mesenteric lymph nodes, liver, lung and peritoneum 8 months after the second surgery.

Case 2. A 64-year-old male with a history of cigarette smoking (BI, 500) who had a cancer of the left pulmonary hilum (pleomorphic carcinoma) underwent chemotherapy. The first regimen, which included cisplatin (CDDP; $80 \mathrm{mg} / \mathrm{m}^{2}$ ) plus vinorelbine (VNR; $25 \mathrm{mg} / \mathrm{m}^{2}$ ), was stopped due to the occurrence of diarrhea. The second regimen was carboplatin (area under the plasma concentration time curve 5) plus gemcitabine $\left(1,000 \mathrm{mg} / \mathrm{m}^{2}\right)$. The patient suffered a recurrence in the mediastinal lymph node 14 months after chemotherapy and radiation therapy (60 Gy/30 fr) was performed. The metastatic lymph node demonstrated a complete response. A solitary omental tumor appeared 46 months and 70 months after the initial start of treatment and the patient was subjected to surgery twice. Physical examination was not noteworthy. The laboratory examination revealed a CEA of $20.6 \mathrm{ng} / \mathrm{ml}$ and a CA19-9 of $5 \mathrm{U} / \mathrm{ml}$ at the first recurrence. The second recurrent case revealed a CEA of $14.3 \mathrm{ng} / \mathrm{ml}$ and a CA19-9 of $12 \mathrm{U} / \mathrm{ml}$. A CT scan revealed an abdominal tumor measuring $34 \times 23 \mathrm{~mm}$ around the stomach for the first time (Fig. 2A). The SUV Max for the first recurrent omental tumor was 8.944 from the PET/CT (Fig. 2B). The second recurrence appeared beside the transverse colon as a $30 \times 25-\mathrm{mm}$ enhanced tumor. Laparotomy was performed twice and each solitary nodule was identified in the greater omentum. The histological examination confirmed that the omental tumor was a metastasis from lung pleomorphic carcinoma. The second recurrent tumor was also identical to the primary pleomorphic lung carcinoma. Eight months after the second surgery, recurrent tumors appeared in the pancreas, para-aortic lymph nodes and the peritoneum, and the patient underwent chemotherapy (pemetrexed; $500 \mathrm{mg} / \mathrm{m}^{2}$ ).

Case 3. A 59-year-old male with a history of cigarette smoking (BI, 1140) who suffered a cancer of the left pulmonary hilum (pleomorphic carcinoma) underwent chemotherapy. The regimens used were CDDP $\left(80 \mathrm{mg} / \mathrm{m}^{2}\right)$ plus VNR $\left(25 \mathrm{mg} / \mathrm{m}^{2}\right)$. 
A

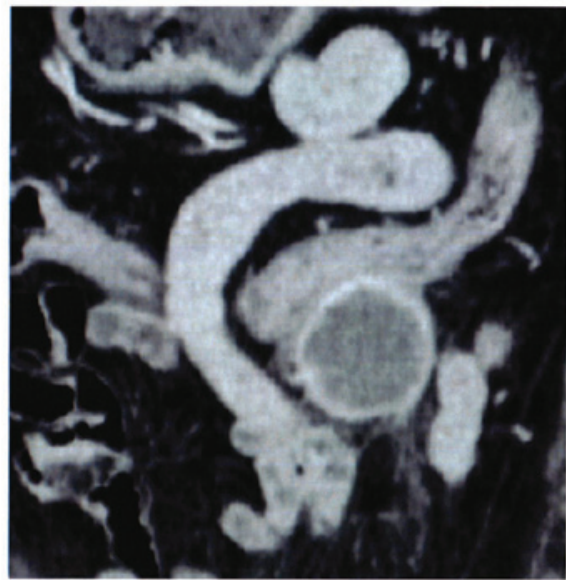

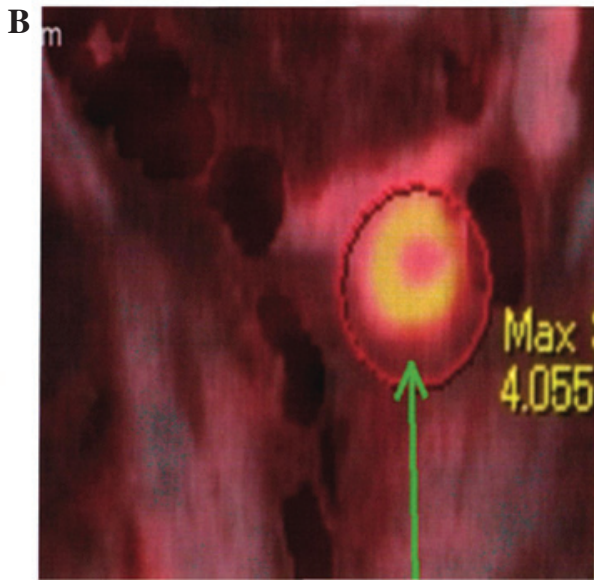

Figure 1. (A) Enhanced computed tomography revealed a tumor adjacent to the transverse colon. (B) ${ }^{18}$ F-fluorodeoxyglucose (FDG) accumulation was observed at the same site with FDG positron emission tomography/computed tomography (arrow indicates omental metastatic tumor).

A

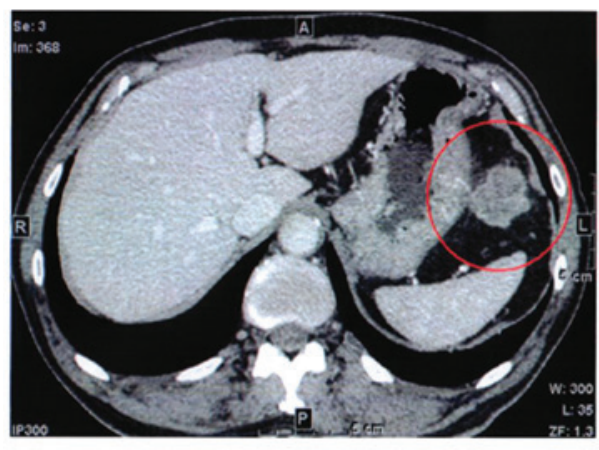

B

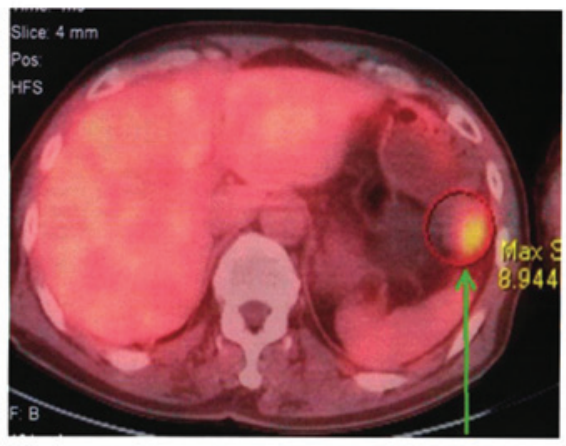

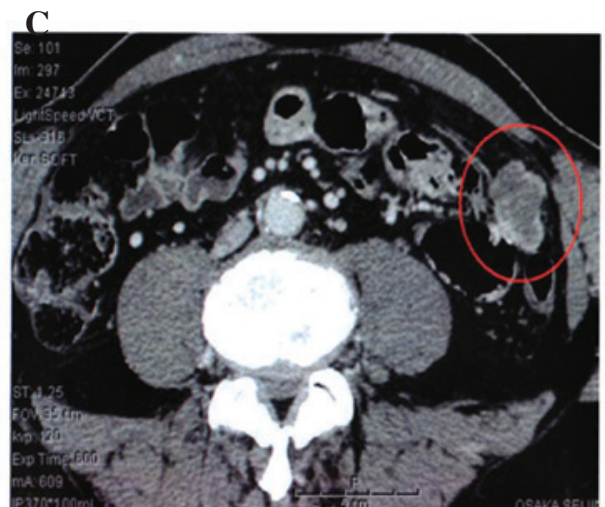

Figure 2. (A) Enhanced computed tomography revealed a tumor adjacent to the stomach. (B) ${ }^{18}$ F-fluorodeoxyglucose (FDG) accumulation was observed at the same site with FDG positron emission tomography/computed tomography (arrow indicates omental metastatic tumor). (C) Enhanced computed tomography revealed a tumor adjacent to the transverse colon.

A

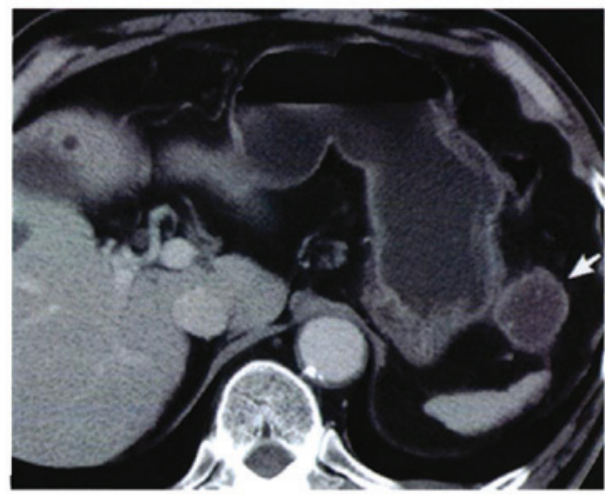

C

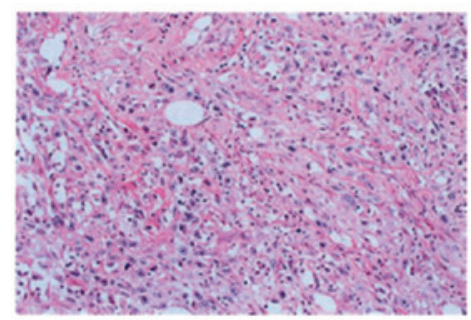

D

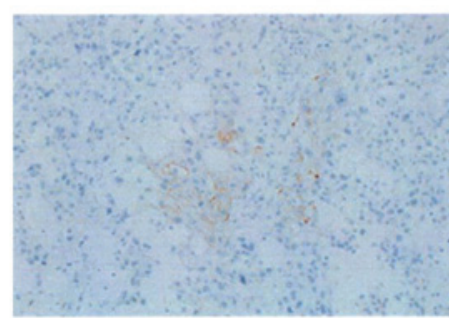

B
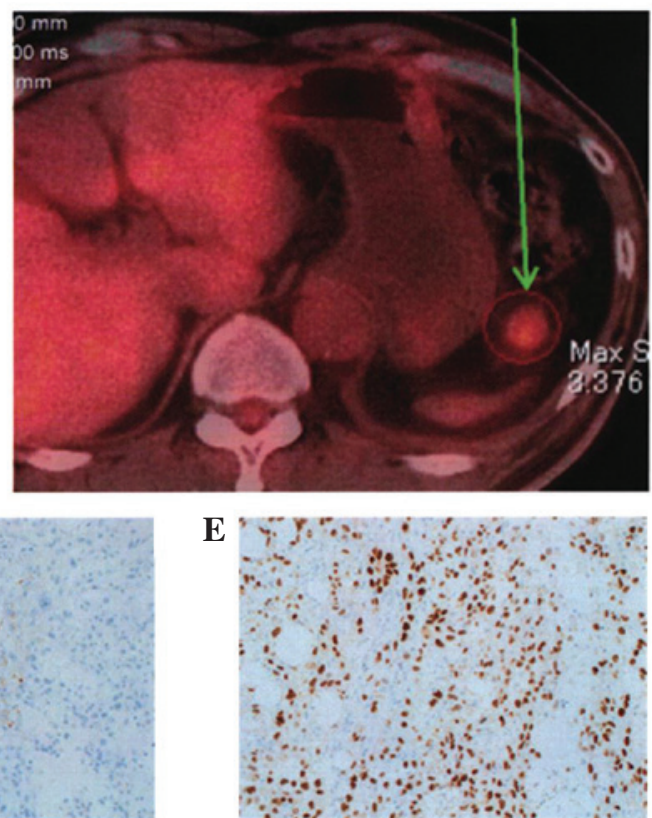

Figure 3. (A) Enhanced computed tomography revealed a tumor adjacent to the stomach. (B) ${ }^{18}$ F-fluorodeoxyglucose (FDG) accumulation was observed at the same site with FDG positron emission tomography/computed tomography (arrow indicates omental metastatic tumor). (C) Photomicrogram of omental tumor specimen with hemotoxylin and eosin staining (magnification, x400). (D) Immunohistochemical analysis revealed cytokeratin 5/6 positivity for tumor cells (magnification, x400). (E) Immunohistochemical analysis revealed p63 positivity for tumor cells (magnification, x400). 
A solitary abdominal tumor was detected with CT 6 months after the start of chemotherapy, and the patient was referred for surgery. Physical examination was not noteworthy. Laboratory studies revealed a CEA of $1.7 \mathrm{ng} / \mathrm{ml}$, cytokeratin 19 fragment of $12 \mathrm{U} / \mathrm{ml}$ (normal range, $0-2.8 \mathrm{ng} / \mathrm{ml}$ ) and neuron specific enolase of $11.6 \mathrm{ng} / \mathrm{ml}$ (normal range, $<16.3 \mathrm{ng} / \mathrm{ml}$ ). CT examination revealed an intra-peritoneal tumor measuring $28 \times 26 \mathrm{~mm}$ around the stomach (Fig. 3A). The SUV Max was 3.376 with PET/CT (Fig. 3B). The tumor had infiltrated into the stomach wall and pancreas tail, and it was resected with a combination of partial gastrectomy, distal pancreatectomy and splenectomy. The histological examination revealed that tumor cells had invaded into the spleen, pancreas and stomach wall, accompanied by massive vascular invasion. The tumor cells were composed of spindle-shaped polygonal tumor cells and demonstrated no clear differentiation trend (Fig. 3C). Immunohistochemical examination revealed that the tumor cells expressed vimentin cytokeratin 5/6, anti-cytokeratin CAM5.2 and p63, but did not express TTF-1 and Napsin A (Fig. 3D and E). Postoperative chemotherapy $\left(\mathrm{S}-1,80 \mathrm{mg} / \mathrm{m}^{2}\right)$ was performed. The patient demonstrated no recurrence 20 months after surgery.

\section{Discussion}

In this study, we have reported three cases of an extremely rare solitary metastatic omental tumor from NSCLC, which had been surgically resected at our department. The three cases that we experienced were incidentally diagnosed with $\mathrm{CT}$ and/or PET-CT and had no symptoms. There have only been a few studies of solitary omental metastasis from NSCLC. Therefore, we reviewed a total of seven cases, comprising four cases reported in the past (8-10) and our three cases. The characteristics of the patients as well as the treatment administered and the outcome of treatment are shown in Tables I and II. The mean age of patients was 58.6 (44-72) years old. The male to female ratio was 6:1. A history of smoking was observed in all patients. Surgical resection for omental tumors was performed in all cases. The histology of the primary site revealed pleomorphic carcinoma in three cases out of seven (43\%). Considering that pleomorphic carcinoma in NSCLC is extremely rare $(0.3 \%$ of all lung cancers), omental metastasis is assumed to be relatively common in pleomorphic carcinoma of the lung (11). Pulmonary pleomorphic carcinoma was identified as a specific type of lung cancer with pleomorphic sarcomatoid or sarcomatous elements by the 1999 World Health Organization classification (12). Pulmonary pleomorphic carcinoma has a more aggressive clinical course and demonstrates a poorer outcome than other NSCLCs $(11,13,14)$. Fujiwara et al reported on cases of gastrointestinal metastasis of NSCLCs (15). These authors reported that three cases out of nine with gastrointestinal metastasis revealed a histology of pleomorphic carcinoma. These results indicate that pulmonary pleomorphic carcinoma has a tendency to metastasize to the abdominal region. Previous studies reveal that the common extrathoracic metastatic sites are the brain (32\%), bone (23\%), liver (9\%), adrenal gland (6\%) and gastrointestinal tracts $(0.5 \%)(7,15,16)$. Omental metastasis of NSCLC is extremely rare and studies of solitary omental metastasis which were subjected to surgery are few. Omental metastasis from NSCLC is considered to be formed through the vascular or lymphatic vessels. Oshika and Hashimoto reported on two patients who suffered gastric wall metastasis following resection of omental metastasis, which may indicate that lung cancer cells first metastasize to the gastric wall through the vascular vessels and then metastasize to the omentum through the lymphatic vessels (9). Stomach metastasis from NSCLC is also extremely rare and there have been few studies to date $(17,18)$.

Due to the limited number of cases with solitary omental metastasis, the significance of the surgical approach for solitary omental carcinoma remains unclear. Table II reveals that with the exception of two patients (\#4 and our case 1), the patients survived more than one year; our case 2 survived 40 months and case 3 survived 20 months following resection of omental metastasis. Therefore, surgical intervention for solitary omental metastasis from NSCLC should be considered if no other metastasis is detected. Chemotherapy following resection of omental metastasis may be required, since long-time survivors (our case 2 and 3) continued postoperative chemotherapy.

In conclusion, although omental metastasis from NSCLC is extremely rare, it should be considered when a patient with history of NSCLC, particularly if the histology is pleomorphic carcinoma, has a solitary tumor around the stomach. Surgical resection for solitary omental metastasis from NSCLC may be indicated if no other metastasis is detected.

\section{References}

1. Jemal A, Bray F, Center MM, Ferlay J, Ward E and Forman D: Global cancer statistics. CA Cancer J Clin 61: 69-90, 2011.

2. Iyer S, Roughley A, Rider A and Taylor-Stokes G: The symptom burden of non-small cell lung cancer in the USA: A real-world cross-sectional study. Support Care Cancer 22: 181-187, 2014.

3. Lozano R, Naghavi M, Foreman K, et al: Global and regional mortality from 235 causes of death for 20 age groups in 1990 and 2010: A systematic analysis for the Global Burden of Disease Study. Lancet 380: 2095-2128, 2012.

4. Morgensztern D, Ng SH, Gao F, Govindan R: Trends in stage distribution for patients with non-small cell lung cancer: A National Cancer Database survey. J Thorac Oncol 5: 29-33, 2010.

5. Rubins J, Unger M, Colice GL and the American College of Chest Physicians: Follow-up and surveillance of the lung cancer patient following curative intent therapy: ACCP evidence-based clinical practice guideline (2nd edition). Chest 132 Suppl 3: S355-S367, 2007.

6. Arriagada R, Bergman B, Dunant A, et al: Cisplatin-based adjuvant chemotherapy in patients with completely resected non-small-cell lung cancer. N Engl J Med 350: 351-360, 2004.

7. Sugimura H, Nichols FC, Yang P, Allen MS, Cassivi SD, Deschamps C, Williams BA and Pairolero PC: Survival after recurrent nonsmall-cell lung cancer after complete pulmonary resection. Ann Thorac Surg 83: 409-417, 2007.

8. Nakamura T, Jibiki M, Ikari H, et al: A case report of unknown-origin tumor metastasized to mediastinal lymph nodes and omentum. Haigan Jpn J Lung Cancer 33: 793, 1993.

9. Oshika Y and Hashimoto H: Two cases of non-small cell lung cancer with metastasis to the omentum. Haigan Jpn J Lung Cancer 48: 118-122, 2008.

10. Tamura R, Kobayashi H, Imai Y, et al: A case report of omental metastasis of pleomorphic carcinoma of the lung which regrowed surprisingly fast after surgical resection. Jpn J Gastroenterol Surg 43: 299-305, 2010.

11. Rossi G, Cavazza A, Sturm N, et al: Pulmonary carcinoma with pleomorphic, sarcomatoid, or sarcomatous elements: a clinocopathologic and immunohistochemical study of 75 cases. Am J Surg Pathol 27: 311-324, 2003.

12. Travis WD, Colby TV, Corrin B, et al (eds): Histological Typing of Lung and Pleural Tumours (World Health Organization, International Histological Classification of Tumours). 3rd edition. Springer, New York, 1999.

13. Fishback NF, Travis WD, Moran CA, et al: Pleomorphic (spindle/ giant cell) carcinoma of the lung. A clinicopathologic correlation of 78 cases. Cancer 73: 2936-2945, 1994. 
14. Mochizuki T, Ishii G, Nagai K, Yoshida J, Nishimura M, Mizuno T, Yokose T, Suzuki K and Ochiai A: Pleomorphic carcinoma of the lung clinicopathological characteristics of 70 cases. Am J Surg Pathol 32: 1727-1735, 2008.

15. Fujiwara A, Okami J, Tokunaga T, Maeda J, Higashiyama M and Kodama K: Surgical treatment for gastrointestinal metastasis of non-small-cell lung cancer after pulmonary resection. Gen Thorac Cardiovasc Surg 59: 748-752, 2011

16. Antler AS, Ough Y, Pitchumoni CS, Davidian M and Thelmo W: Gastrointestinal metastases from malignant tumors of the lung. Cancer 49: 170-172, 1982.
17. Nakamura H, Mizokami Y, Iwaki Y, Shiraishi T, Ohtsubo T and Miura S, et al: Lung cancer with metastases to the stomach and duodenum. Reports of three cases. Dig Endosc 15: 210-215, 2003.

18. Aokage K, Yoshida J, Ishii G, et al: Long-term survival in two cases of resected gastric metastasis of pulmonary pleomorphic carcinoma. J Thorac Oncol 3: 796-799, 2008. 